\title{
Ny geologi på Bornholm
}

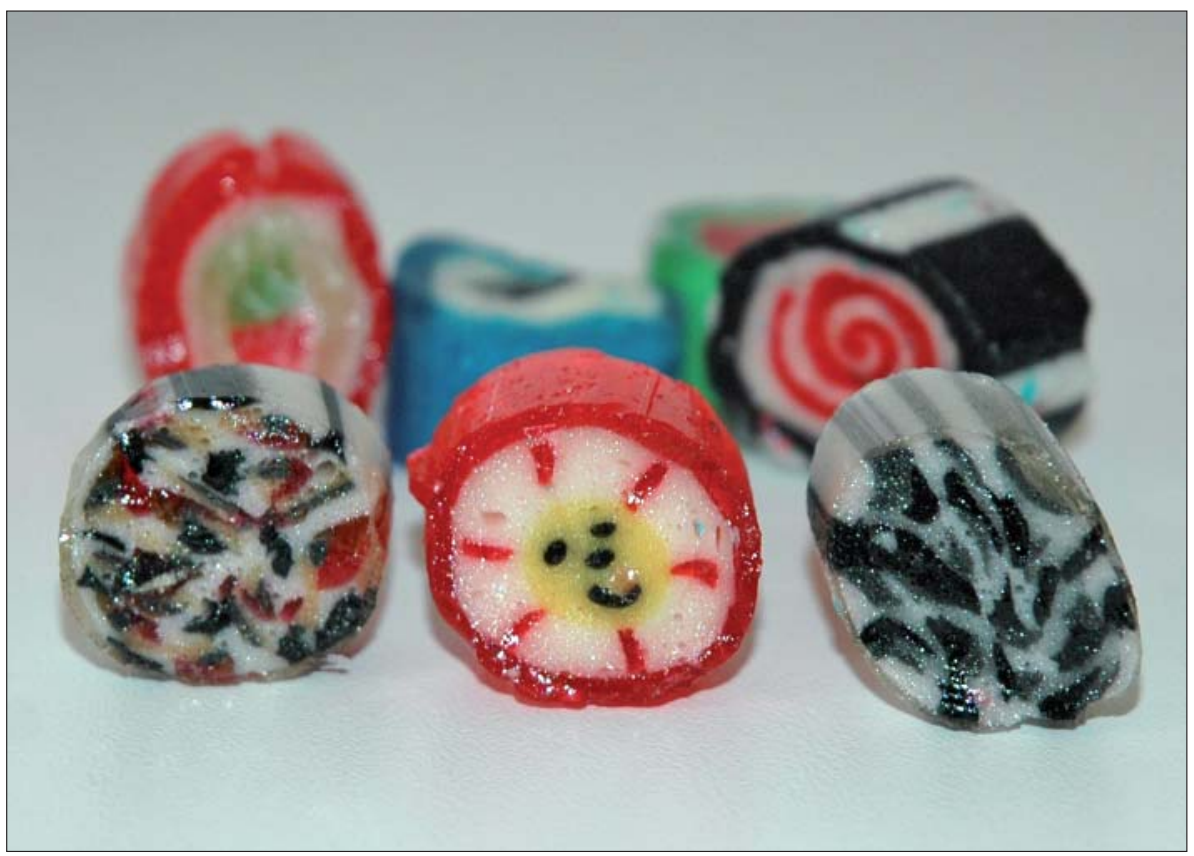

"Svaneke-bolcher på solskinsøen har lanceret en geologisk serie med bornholmsk granit og gnejs"! (Foto: Forfatteren)

Af GeologiskNyts webmaster Steen Laursen

Bornholm har fået nye attraktioner for geologer, og de egner sig for hele familien.

På geologistudiet udreder lektorer, professorer og andet godtfolk en masse pudsige forklaringer på mange mærkelige former og fænomener. Men selv logik, matematik og stakke af hulkort har deres begrænsninger som forklarende medier.

\section{Svaneke-bolcher}

Men i Svaneke-Bolcher ruller de beviser ud for store, blanke børneøjne. Her bygger den gæve bolchemager sin sukkermasse op til en figur, og deformerer den så det batter. I dag er det en sort raket med styrefinner og det hele. Den er spids og kantet de rigtige steder, og alle huller i figuren fylder han ud med en passende baggrundsfarve.

Da det hele er pakket ind i endnu mere bolchemasse, starter han deformationen, og efter en lille halv time har han bevist, at professorerne har ret. Hvert eneste af de nyskabte bolcher har en perfekt gengivelse af raketten, men i mindre end en tyvendedel størrelse.

\section{Vinderosion}

Det der med, at vinden skulle have nogle alvorlige opbyggende og nedbrydende egenskaber, virker også mest som en påstand, når den bliver luftet $i$ et lokale, hvor støvet ikke har flyttet sig, siden taget kom på instituttet.
Men bornholmerbåden fra Ystad til Rønne er overbevisende på den brølende måde.

Færgen sejler med 70-80 kilometer i timen - to tredjedel af en orkans hastighed - så her er der altid en grundig forelæsning på dækket. Desværre kan man ikke komme ud på fordækket, men agterdækket er også ganske godt eksponeret. Og over det frådende skum af vand agterude står forstøvet vand som hvirvlende søjler på grænsen mellem den stille luft over havet og det vilde vejr bag skibet.

\section{Den fossile vandmand}

NaturBornholm har også fået ny geologi. Ikke alene har de aftryk af aftrykkene af en dinosaurers fødder - de originale fodspor sidder stadig i klinten - nu har de også aftryk af seks vandmænd. Naturvejlederne fandt dem for et par år siden nede $i$ centrets eget stenbrud. Et af de bløde kræ ligger stadig dernede til glæde for turisterne, og resten af aftrykkene er portrætteret vha. aftryk inde $i$ centret.

\section{Klipper i massevis}

Nå ja, så er der jo også en masse klipper på Bornholm. Og også her er der nyt fra Bornholm. For hvor man på Mallorca kan købe vandfyldte kuglepenne med mænd og kvinder - især kvinder - der mister hver en trevl ved et vip med pennen, så byder NaturBornholm nu på en kuglepen med granitstykker i vand. Den kan ikke demonstrere nogen geologiske kræfter, men den koster kun 30 kroner. 